\title{
Информационная база анализа сенсорных терминалов образовательных учреждений
}

\author{
Романов А.А., студент, \\ Технический институт (филиал) \\ Северо-Восточного федерального университета, \\ 2. Нерюнгри \\ E-mail: rom_ykt@mail.ru
}

\section{Научный руководитель: к.2.-м.н., доцент Мололкина О.Л.}

В высших учебных заведениях сенсорные информационные терминалы также нашли свое применение. Благодаря им студент может узнать историю учебного заведения, ознакомиться с составом обучающего персонала, узнать намеченные мероприятия и расписания лекций, а также получить результаты тестов, зачетов и экзаменов.

Зачастую информационные терминалы незаменимы в библиотеках, когда нужно быстро найти необходимую книгу. Помимо того, терминал может содержать в себе информацию об авторе книги, список его произведений, а также рецензии.

Можно реализовать функции заказа печати и/или копирования учебных пособий.

Интерактивные сенсорные терминалы помогают планировать процесс обучения, предоставляют образовательные и справочные услуги. Сенсорные терминалы могут быть размещены в специальных местах, обеспечивающих удобство, комфорт и концентрацию внимания пользователя.

Терминал не занимает много места, так как он может стоять на полу или может быть встроен в стену и является законченным аппаратно-программным комплексом, который может быть соединен с внутренней информационной системой или с интернетом.

Кроме того, предлагаемая нами система позволяет ученикам вести дневник домашних заданий, а преподавателям - управлять работой слушателя на занятии. Ученик может использовать материалы лекций, делать собственные конспекты, а учитель - переносить уроки в другие классы и школы. Платформа сенсорных терминалов способна интегрировать любое ПО, в том числе и разработки другой компании.

Интеллектуальная поддержка современных технологий позволяет ученику быть более уверенным в своих силах. Результаты экспериментов, проведенных в ряде учебных заведений как в России, так и за рубежом показывают, что дети, занимающиеся по электронным учебникам, значительно опережают своих сверстников в развитии и гораздо легче осваивают новые дисциплины.

Сенсорные терминалы могут быть установлены:

- в вестибюле учебного заведения, чтобы предоставить студентам информацию об учебном заведении, условиях обучения, расписании занятий, общественных и культурных мероприятиях;

- в деканатах или кафедрах, где студенты могут получить более подробную информацию (оценки, даты экзаменов, списки преподавателей, сроки сдачи курсовых работ и так далее); 
- в классах для управления презентационным и мультимедийным оборудованием;

- в залах заседаний, чтобы слушатели могли следить за ходом презентации на своем сенсорном мониторе и помечать страницы, которые они хотели бы распечатать;

- в библиотеке сенсорный терминал, соединенный с электронной базой, позволяет студентам подбирать необходимые книги, чтобы упростить и ускорить процесс выдачи книг.

- для проведения экзаменов и тестов, заполнения анкет, когда нужно ввести минимум данных с помощью всплывающей клавиатуры и выбрать правильный вариант ответа на вопрос.

Информационный терминал - это терминал доступа к информационному порталу вуза, на котором может размещаться вся учебная, административная и научная информация университета: новости, расписание занятий, задания к семинарам, результаты экзаменов, приказы и распоряжения, персональные страницы преподавателей, база знаний и многое другое.

Полностью портал доступен через Интернет, а информационный терминал предполагает недолгую работу с ним - получение оперативной информации о расписании занятий, результатах экзаменов и т.п.

Чтобы попасть на портал через инфотерминал, студент должен ввести свой логин и пароль аналогично тому, как если бы он заходил на портал с компьютера через Интернет. Другой вариант авторизации - воспользоваться многофункциональной картой студента. В этом случае инфотерминал считывает данные с карты, как банкомат, идентифицирует студента и предоставляет ему соответствующие права доступа. С помощью многофункциональных карт студентов и преподавателей можно получать не только доступ к информационным ресурсам. Карта может служить электронным пропуском в здания и помещения, электронной зачетной книжкой, электронным читательским билетом в библиотеке, платежной картой при оплате питания в столовой, ксерокопирования и печати учебных материалов. На карте также может храниться персональная информация студента, информация о его успеваемости и платежах за оказанные ему услуги.

Использование сенсорной панели в данном случае позволяет избавиться от множества пультов управления, а также дает возможность создавать сценарии. Управляющие кнопки представлены в виде понятных графических иконок. Все оборудование подключается к компьютеру и с помощью специального программного обеспечения управляется прикосновением пальца к сенсорному монитору. Кроме того, терминал вандалоустойчив, что особенно важно в условиях учебных заведений, так что можно не бояться за сохранность оборудования.

Интерфейс, информационное наполнение:

- Общая информация о школе, контакты;

- Сообщения и объявления для учителей, учащихся и их родителей;

- Информация о педагогическом составе;

- Виртуальная доска почета учащихся и преподавателей школы;

- Информация о книгах, находящихся в школьной библиотеке;

- Расписание занятий;

- Расписание внеклассных мероприятий;

- Информация о секциях, кружках и факультативах, работающих в школе; 
- Обратная связь с учителями, учащимися и их родителями (отзывы, опросы, анкеты, голосования и пр.);

- Поисковая система;

- Прогноз погоды;

- Часы, Календарь;

Рекламодатели:

- Клубы и кружки по интересам;

- Спортивные секции;

- Музыкальные школы;

- Книжные магазины;

- ВУЗы.

Уже сегодня многие ученики и студенты образовательных учреждений оценили все достоинства сенсорного терминала. Внедрение информационных технологий в образовании означает переход на качественно новый уровень обучения, а это жизненно важно и диктуется общим прогрессом человечества.

\section{Список литературы:}

1. Довгаль В.М., Волобуев В.В. Стационарный терминал как средство визуализации документальной информации в образовательном учреждении В.М. Довгаль, В.В. Волобуев Известия Юго-Западного государственного университета. 2009. - № 3. - С. 54-58.

2. Избачков Ю.С., Петров В.Н. Информационные системы: Учебник для вузов Ю.С. Избачков, В.Н. Петров. - 2-е изд. - СПб.: Питер, 2006. - 656 с.

3. Колесникова О.В. Электронный учебник как средство информатизации общества О.В. Колесникова Вестник Псковского государственного педагогического университета. - 2010. - № 10. - С. 62-67.

4. Купер А., Рейман Р., Кронин Д. Алан Купер об интерфейсе. Основы проектирования взаимодействия А. Купер, Р. Рейман, Д. Кронин. - Пер. с англ. - СПб.: Символ-Плюс, 2009. - 688 с.

5. Трайнев В.А. Новые информационные коммуникационные технологии в образовании В.А. Трайнев, В.Ю. Теплышев, И.В. Трайнев. - М.: Издательско-торговая корпорация «Дашков и К», 2009. - 320 с. 